\title{
EKSISTENSI AMANAT KEAGUNGAN ILAHI (AKI) PERSPEKTIF FUNGSIONALISME DURKHEIM
}

\author{
THE EXISTENCE OF GOD SUPREME (GSA): \\ THE PERSFECTIVE OF DURKEIM FUNGSIONALISM
}

\author{
Firman Nugraha \\ Balai Diklat Kegamaan Bandung \\ Jl. Soekarno Hatta No.716, Babakan Penghulu, Cinambo, \\ Kota Bandung, Jawa Barat 40294 \\ Email: phiemanbdg@gmail.com
}

Naskah diterima tanggal 4 Agustus 2016. Naskah direvisi tanggal 30 September 2016. Naskah disetujui tanggal 9 November 2016.

\begin{abstract}
Abstrak
Tujuan penulisan artikel ini untuk mendeskripsikan fenomena kelompok Amanat Keagungan Ilahi yang menyangkut keberfungsian ajaran, makna dan kolektifitas sosial para penganutnya. Data-data dan informasi diperoleh dari dokumen hasil kajian terdahulu dan hasil wawancara dengan partisipan yang merupakan anggota AKI, maupun copy transkrip ajaran yang berlaku di lingkungan AKI. Analisis menggunakan perspektif fungsionalisme Durkheim yang menyatakan keyakinan beragama tidak hanya berkenaan dengan dimensi sakral yang bersifat personal melainkan juga kekolektifan. Hasil analisis menunjukkan bahwa ikatan primordial yang kuat atas kelompok oleh penganutnya didorong bukan hanya karena adanya motivasi sipiritual yang ditawarkan dalam ajaran AKI, melainkan juga adanya dukungan intimasi sosial yang kuat antar anggota sehingga mereka merasakan kenyamanan dan kebermaknaan dalam AKI. Kondisi ini meneguhkan konsep Durkheim bahwa keyakinan yang fungsional cenderung bertahan dan dipertahankan pemeluknya.
\end{abstract}

Kata kunci: Agama, kolektifitas sosial, masyarakat, sistem.

\begin{abstract}
The purpose of writing this article is to describe the phenomenon of group Amanat Keagungan Ilahi (AKI) concerning the functioning of the doctrine, meaning and social collectivity adherents. The data and information obtained from the documents the results of previous studies as well as a copy of the transcript doctrine prevailing in the AKI. And interviews with participants who are members of AKI. Analysis using the perspective of functionalism Durkheim that stating the religious beliefs not only with respect to the sacred dimension that are personal but also collectivity. The analysis showed that the primordial strong bond over the group by its adherents are encouraged not only because of the motivation sipiritual offered in AKI teachings, but also the support of a strong social intimacy between members so that they feel the comfort and meaningfulness in AKI. This condition confirms Durkheim concepts that functional beliefs tend to survive and maintain its adherents.
\end{abstract}

Keywords: Religion, social collectivity, society, system

\section{PENDAHULUAN}

$\mathrm{J}$ auh sebelum hadirnya agama-agama besar saat ini, manusia telah berupaya untuk menemukan suatu hubungan khusus antara dirinya dengan Sesuatu Yang Luar Biasa dan berinteraksi denganNya. Menurut E.O James (1964:1) hal ini merupakan konsekuensi dimensi spiritual yang ada dalam diri manusia. Kesadaran religius ini menurut Komarudin Hidayat (1995: 36) memang menjadi potensi primordial manusia termasuk manusia paling primitif sekalipun. Pergulatan manusia dari yang primitif sampai modern dalam mencari agama tampaknya tidak bertepuk sebelah tangan. Tuhan turun tangan memberikan sinyal melalui para nabi dan orang-orang suci mengenai keberadaanNya. Upaya ini sebagai jawaban Tuhan atas kegelisahan manusia dan membimbing manusia menuju ke arah yang "diinginkan" oleh Tuhan dan membawa manusia dalam kehidupan yang paripurna baik 
secara duniawi-ukhrawi maupun mental-psikologis dan fisik-indrawi (Syariati, 2000: 36).

Pergulatan manusia dengan agama sampai hari ini tidak selesai pada titik kepuasan dengan adanya agama-agama mainstream (Bruinessen, 1992: 16-27) Di balik itu tetap saja manusia mencari bentuk-bentuk lain dan semangat lain baik yang masih memiliki ciri dari agama yang mereka anut sebelumnya atau melakukan konversi agama. (James, 2015, 193-256 ) Tindakan konversi agama sesungguhnya bagi agama yang ditinggalkannya menjadi suatu bentuk pelanggaran, pun demikian dengan adanya kreasi lain dari garis mainstream dalam agama yang telah dianutnya. Konsep ini sering disebutkan dengan sekte, atau deviasi dari agama mainstream. Meski masih menunjukkan ciri umum dari agama mainstream yang dianutnya namun berpotensi melahirkan ketegangan horizontal. Karena agama pada ahirnya berbicara mengenai pengikatan pemeluknya melalui serangkaian ritual yang berdampak pahala dan dosa.

Atas fenomena lahirnya deviasi atau konversi ini yang dalam konteks ke- Indonesiaan mengalami dua periode rezim dengan kendali yang berbeda atas "agama" berimplikasi pada respon masyarakat agama itu sendiri dalam mengidentifikasi diri sebagai bagian dari kelompok tertentu. Orde baru dengan ciri khasnya stabilitas nasional dan kendali ketat dari pemerintah untuk setiap tindakan penduduk termasuk dalam berkeyakinan dan beragama tampak telah "sukses" untuk mengidentifikasi keberagamaan penduduknya pada dua besaran, beragama formal dan berkeyakinan (Rozak, 2005: 147). Hal berbeda terjadi di era reformasi, sebagai imbas dari euphoria demokrasi pihak-pihak yang sebelumnya "tersembunyi" dalam bayang-bayang kelompok mainstream baik agama maupun keyakinan kebatinan, mereka mengemuka menuntut pengakuan atas eksistensinya. Maka, secara sepintas terkesan era ini membuka pintu deviasi dalam beragama dan berkeyakinan secara terbuka (Laporan Balai Litbang Keagamaan Jakarta, Tahun 2013).

Salah satu yang menarik untuk dikaji adalah kelompok Amanat Keagungan Ilahi. Kelompok ini sudah ada sejak orde baru masih berkuasa, dan sampai hari ini masih eksis meskipun mendapat resiko tertentu. Seperti dilaporkan hasil penelitian BalaiLitbang Agama (2013) merekayang menjadianti mainstream akan mendapat stigma sesat. Beberapa penelitian terdahulu juga cenderung menunjukan kelompok ini sebagai ajaran yang cenderung sesat dengan parameter teologis (Nugraha, 2013. Website bdkbandung.kemenag.go.id./journal/2013). Karena bentuk umumnya masih menunjukkan ciri agama Islam, maka parameter yang digunakan oleh kajiankajian awal adalah fatwa MUI dan parameter ajaran Islam (Ma’mun, 2013: 125-149). Namun demikian dalam penelitian lain, Asary misalnya menunjukkan bahwa kelompok ini telah terpecah dan diantara mereka ada yang tidak digolongkan sesat (Asy'ary, 2009).

Kajian sederhana ini tidak dalam kapasitas untuk menunjukkan sisi sesat atau tidak sesatnya kelompok ini, namun dalam upaya untuk menemukan jawaban atas pertanyaan masalah bagaimana konsepsi makna dan keberfungsian ajaran AKI dalam merawat kolektifitas para anggotanya?

\section{Tinjauan Pustaka}

Untuk mendeskripsikan secara teoritik atas pertanyaan tersebut, maka digunakan teori fungsionalisme Durkheim. Teoriini dipengaruhioleh pemikiran biologis, yang menganggap masyarakat sebagai organisme yang terdiri dari organ-organ yang saling ketergantungan.Ketergantungan ini terjadi sebagai konsekuensi agar organisme tersebut tetap dapat bertahan hidup.Durkheim berpendapat bahwa masyarakat adalah sebuah kesatuan yang di dalamnya terdapat bagian-bagian dengan fungsi masing-masing yang membuat sistem menjadi seimbang. Bagian tersebut saling ketergantungan antara satu sama lainnya dan fungsional. Sehingga jika ada yang tidak berfungsi maka akan merusak keseimbangan sistem.

Mengapa manusia beragama atau memerlukan agama tampaknya menjadi pertanyaan mendasar yang telah menarik minat banyak sarjana dan mencoba mendeskripsikan (tentu) sesuai dengan disiplin ilmu yang menjadi basis pemikiran mereka. Semisal Wiliam James (2015: 14-18) sebagai filsuf yang juga ahli di bidang psikologi menjawab pertanyaan kecenderungan beragama sebagai nuansa batiniah manusia yang menjadi pengalaman religius setiap umat manusia. Dalam perspektif ini mungkin kita berkata pada ahirnya agama itu sangat personal, sebab sulit untuk menemukan pengalaman religius yang sama untuk setiap manusia. Tetapi kita juga menyaksikan adanya kolektifitas dalam beragama. Sifat kekelompokan ini niscaya salahsatunya ditopang oleh perasaan atau pengalaman yang mirip dari masing-masing anggota atau pemeluk. Menurut Durkheim (1995: 
37), hal tersebut terjadi karena pada akhirnya agama bukan hanya persoalan tentang tuhan atau spirit, dan untuk itu ia mendefinsikan agama sebagai sekumpulan keyakinan dan praktek yang berkaitan dengan sesuatu yang sakral yang menyatukan satu komunitas tunggal.

Agama bagi Durkheim dipandang sebagai sumber utama solidaritas sosial (1995: 395). Ritual agama yang dilakukan secara kolektif dapat memperkuat solidaritas. Semakin inklusif terhadap agama tersebut, pada saat yang sama semakin eksklusiv terhadap kelompok-kelompok agama yang lain. Solidaritas ini menjadi solidaritas baru yang didasarkan pada kesadaran terhadap kondisi pluralitas yang terbentuk apabila apabila dalam masyarakat yang telah mengalami proses individualisasi itu telah timbul kesadaran adanya saling ketergantungan di antara mereka dan timbul pula rasa saling membutuhkan. Dalam konteks AKI, ritual yang bersumber dari ajaran diduga akan meneguhkan kolektifitas di antara anggota mereka. Semakin dinilai fungsional dalam realitas doktrin, maka semakin kuat solidaritas yang terbangun di antara mereka.

\section{METODE PENELITIAN}

Studi ini dilakukan dengan pendekatan kualitatif (Mulyana, 2006: ix). Informasi diperoleh melalui wawancara pada partisipan yang ditentukan yaitu unsur pemerintah dan pengikut yang berada di lingkaran utama AKI. Lain dari itu juga dilakukan pemeriksaan atas data-data pada dokumen yang berkaitan dengan subjek studi baik data internal maupun data eksternal dari pihak-pihak yang berhubungan dengan subjek studi seperti laporan penelitian terdahulu, seperti Lembaran Amanat M. Syamsoe; Protap AKI yang disusun oleh Firman 40 (AKI Andreas) di Jakarta; transkrip rekaman wawancara dan rekaman ceramah Mas Min tokoh AKI dari Bandung saat haul M. Syamsoe serta suratsurat resmi dari Kejaksaan, MUI tentang AKI. Data dan informasi tersebut dianalisis dengan tahapan, reduksi, kategorisasi, penafsiran, verifikasi dan penyimpulan (Sugiyono, 2009)

\section{PEMBAHASAN}

Amanat Keagungan Ilahi: Deskripsi dan Analisis Sekilas Sejarah AKI dan Perkembangannya

Amanat Keagungan Ilahi selanjutnya disingkat AKI merupakan nama bagi ajaran sekaligus kelompok bagi pengikut ajaran ini. AKI dikenalkan mulai tahun 1969 oleh tokoh pendirinya yaitu Rd. Mohamad Syamsoe (Aki Syamsu) lahir di Bandung pada tanggal 14 September 1932 dan meninggal di Jakarta pada tanggal 7 Juni 1995. Pada tahun 1969 tersebut, M. Syamsoe mengaku mendapat wahyu ketika dia bertapa di Banten pada malam malam 12 Maulud atau 29 Mei 1969 (Asary, 2009; Nurhamidah, 2010; Nugraha, 2013; dan Ma'mun, 2013). Atas dasar wahyu itu ia merasa terpanggil untuk menyebarkan keyakinannya yang sekaligus menjadi tanggung jawab moral dia sebagai insan terpilih.

Sebagai ajaran, AKI merupakan metamorfosis dari kegiatan lain yang bernama Aliran Kepribadian di Jawa Barat ketika M. Syamsoe berdomisili di Bandung. Kemudian ketika diindikasikan terjadi pencampuran pemahaman keagamaan dan berpotensi menjadi ajaran dan kelompok sesat, maka pada tahun 1979 terbit Surat Keputusan Kejaksaan Tinggi Jawa Barat Nomor: Kep-45/K2.3/12/1979 tertanggal 4 Desember 1979 yang pada poin 9 kembali menegaskan kepada kejaksaan negeri di wilayah Jawa Barat untuk kembali membekukan akifitas M. Syamsoe dan pengikutnya (Ma'mun, 2013).

Pada tahun 1982, M. Syamsoe pindah ke Pandeglang dan mengembangkan ajarannya dengan nama Ajaran Takwa. Namun karena masih dibawakan oleh tokoh yang sama dan dasar ajaran yang sama, maka Ajaran Takwa inipun bernasib sama dengan Aliran Kepribadian, harus berujung pada pembekuan kegiatan atas dasar surat Kejaksaan Negeri Serang nomor Kep-002/K.2/22-2/82 tertanggal 24 Februari 1982 (Ma’mun, 2013).

Pada tahun 1991 M. Syamsoe mengembangkan ajarannya di Subang dan Purwakarta dengan nama Amanat Keagungan Ilahi. Kegiatan inipun berujung pada pelarangan dari Kajari Subang nomor Kep01/K2.24/Dsk.3/5/91 tertanggal 1 Mei 1991; dan Kajari Purwakarta dangan nomor Kep-525/K2.20.2/ Dsk.3/5/91 dan dipertegas dengan surat lanjutan dari Kajati Jabar nomor R.538/P2.3/Dsb.1/11/1993 (Ma'mun, 2013).

Setelah M. Syamsoe meninggal dan dimakamkan di Cangkuang, Leles, Garut. Ajaran ini terpecah menjadi tiga besaran sesuai dengan tokoh yang melanjutkannya. Dan menurut studistudi terdahulu di antara bentuk AKI pasca M. Syamsoe ini ada yang terindikasi sesat dan ada yang tidak sesat. Hasil penelitian Asary dari Litbang dan Diklat Kemenag pada tahun 2009 misalnya dalam kesimpulannya AKI yang dipimpin Kurnia Wahyu di Bandung tidak sesat, karena kelompok ini bertransformasi menjadi majlis zikir dan 
tidak dan penyimpangan dari Islam secara umum (Asary, 2009). Kesimpulan ini serupa dengan hasil investigasi Pengawas aliran kepercayaan masyarakat (Pakem) Kabupaten Bandung (Pikiran Rakyat, 24 Maret, 2009). Selain AKI Kurnia Wahyu juga ada AKI Andreas atau Firman 40, dan Amir Bulganon. Mereka bertiga merupakan murid M. Syamsoe yang melanjutkan ajaran dengan versi masing-masing. Bulganon bergabung dengan Syamsoe sejak 1975, sedangkan Kurnia Wahyu bergabung pada 1979. Selain Kurnia, AKI juga dikembangkan di Jakarta oleh Andreas. Nama terakhir ini adalah pengikut Syamsoe yang belakangan bergabung, pada 1986 (Gatra Nomor 13 Kamis, 5 Februari 2009). Bulganon, setelah M. Syamsoe meninggal, ia mendirikan Yayasan Kharisma Usada Mustika (Yaskum) yang bergerak di bidang sosial kemasyarakatan, hukum, pendidikan formal dan informal, kesehatan/ pengobatan, dan pembinaan mental (Gatra Nomor 13 Kamis, 5 Februari 2009; website Yaskum). Di antara tiga kelompok AKI ini, AKI Andreas dinilai sesat oleh Pakem dan MUI sehingga Andreas harus berurusan dengan meja hijau atas pasal penistaan agama.

Di Leles Garut, AKI berkembang seiring dengan dimakamkannya M. Syamsoe di sana. Sebelumnya menurut Ibu Andi (Wawancara, 24/2/ 2016) pada tahun 1993 mereka membeli tanah di sekitar Cangkuang dan 1994 mulai dibangun, kini menjadi pusat kunjungan para murid $\mathrm{M}$. Syamsoe serta pengikut generasi berikutnya. Dimana setiap tanggal 24 selalu ada kumpulan bersama sebagai ajang silaturahmi di antara mereka (Wawancara, 24/2/2016).Sebagai pusat dalam pusaran perkembangan ajaran, AKI di Leles tentu harus mengakomodir seluruh murid M. Syamsoe. Maka menjadi banyak warna dalam AKI di Leles, namun semuanya terikat oleh kesatuan ikrar dalam pewarisan yang menjadi pintu peneguhan batin sesama anggota. Lain dari itu, pada prinsipnya mereka mengamalkan amanat dari M. Syamsoe yang bersumber dari wahyu yang diterimanya ketika bertapa itu (Nurhamidah, 2010).

Selain di Jawa Barat dan Jakarta, Aki juga ditemukan di Sumatera Selatan. Dalam penelitian Mảmun terungkap bahwa AKI di Sumatra Selatan dipimpin oleh Mahidin yang mendapat ajaran ini ketika ia berada di Bandung (Ma'mun, 2013: 137-138). AKI di Sumatera Selatan berpusat di Palembang dan Mahidin memiliki pengikut sekitar 200 orang yang dibantu oleh imam lainnya yaitu Slamet, Aris, Mulyadi dan Ivan. Dalam penelitian
Ma’mun, AKI di Sumatera Selatan ini digolongkan sesat karena beberapa pokok ajarannya dinilai menyimpang dari ajaran Islam.

\section{Pokok Ajaran dan Makna}

Pokok ajaran Aki bersumber kepada amanat M. Syamsoe yang dihayati sebagai wahyu yang diterimanya (Nugraha, 2013). Amanat (Transkrip copy amanat dalam Protap AKI) Antara lain:

\section{Assalamu'alaikum wr.wb.}

Bismillahi tawakaltu illAlloh, lahaola walaquwata illa billahi aliyul adzim, asyhadu ala illaha illAlloh, wa asyhadu anna muhammad rasululloh, demi Alloh rasululloh, wAllohi Alloh hu akbar lillahi taala: holikul insyanu abduhu .... sirotol mustakim.

Sabenerna anjeun palsu micinta ka kami [Alloh] sabenerna anjeun asal timana?Jeung rek kamana? Geura tingali ku anjeun: bumi, langit, bulan, bentang, matahari jeung sakabeh pangeusina alam dunya eta kami [Alloh] anu ngajadikeun!

Dengekeun amanat-amanat kami [Alloh] pikeun aranjeun, kami [Alloh] sengaja anjeun ku kami [Alloh] dirobahkeun hate anjeun, tina kagelapan pikeun anjeun kudu ngarti kana kakuasaan kami [Alloh]

Sebarkeun kanikmatan ti kami [Alloh] anu kuanjeun geus karasa, pikeun ka sasama machluk anjeun, bukakeun hatena tina kagelapanana, yen kami [Alloh] anu berkuasa di dunya teh.

Dosalah anjeun lamun ngoretkeun kana kanikmatan ti kami [Alloh] pikeun ka sasama machlukna.

Sabenerna kami [Alloh] nyaksi tina sakabeh achlak kalakuan anjeun, tina dosa jeung salah ...ulah boga rasa buni tina kasalahan jeung dosa buni soteh ti sasama machlukna, sagede beungeut hate anjeun cumarita, kami geus ngarti, kami leuwih nyaho ti anjeun!

Allohuakbar (aslinya dalam tulisan arab)

Bismillahirrohmannirrohiem,

Assalamu'alaikum wr. Wb.

Upami enya machluk tos ngaku ka gustina ...[tidak jelas] gusti eta: maha ninggali, maha nguping kana sakabeh kalakuan machlukna, yakin palsuna eta pangakuan teh.

Upami enya rasa dirina geus bisa, geus karasa yen dirina disaksian ku gustina; pinasti eta machluk moal bisa berbuat sawenang-wenang, singhoreng machluk teh paralsu tina pangakuannana ka gustina.

Lamun enya mah karasa: disaksi, ditingali ...[tidak jelas] buni tina dosa jeung kasalahanna, 
...[tidak jelas] sasama machluk: gusti maha ningali, gusti ...[tidak jelas] nguping, ngan sa ukur karek bisa ngu...[tidak jelas] horeng simana horeng ngaku bener dirina teu dikoreksi kajero mah hatena teh, kalakuannana teh, pinuh ku kotoran hatena, pinuh $k u$ dosa jeung kasalahan tina kalakuannana.

Cobi hayati dilebetkeun kana manah anu suci sangkan urang jadi abdi Alloh anu sampurna.

Amien ya robbal alamien.

“...Sakumaha ayat-ayat suci al Quran kasebat diluhur, sumangga urang kaitkeun kana naon anu $k u$ urang parantos nyata; karaba sareng karasa, tur anu sanes wartos tisasamana, nyaeta anu ngalangkungan petunjuk 'Amanat Kesucian Illahi' [A.K.I.], anu awal kacarioskeun nyaeta anu ngalangkungan salahsawios hiji jalma lalaki, sakalipun nyaeta anu bersangkutan nyaeta sarirana aki, bakal moal ngangkenna, diantawisna salahsawios ayat/dawuhan gusti Alloh anu katampi ngalangkungan sesepuh utami AKI, diantawisna :

1. Geura dengeukeun ku diri maneh, yen kami [Alloh] ngahaja ngarobahkeun rasa hate/diri maneh, pikeun maneh ngarti ka kami [Alloh].

2. Saha maneh anu sabenerna? Jeung saha kami [Alloh] anu sabenerna?

3. Jeung asal timana diri maneh? Jeung rek kamana diri maneh?

4. Prak geura tuturkeun rasa kami [Alloh] di diri maneh, lamun diri maneh hayang aya dina ridho kami [Alloh].

5. Jeung kami mere beja ka maneh, sing saha anu satia kami [Alloh], niscaya maneh bakal meunang kasenangan dunya /acherat.

6. Ieu jangji kami [Alloh] ka maraneh, jeung maneh cukup nurut kana kahayang kami [Alloh].

7. Pikeun maneh cukup moal ngarti, kana naon anu dipiharep ku kami [Alloh].

8. Eta urusan kami [Alloh], jeung kami leuwih nyaho ti maneh.

9. Oge sabalikna, lamun maneh palsu jeung bohong ka kami [Alloh] berarti maneh ngundang kamiskinan dina urusan hirup maraneh di dunya jeung acheratna.

10. Geura tuturkeun rasa kami [Alloh] di diri maneh, sangkan maneh wawuh jeung kami [Alloh] jeung rasulna.....?

11. Dimana maneh geus wawuh jeung kami [Alloh] katut rasulna, geura prak syukuran ka kami jeung rasulna!!!

12. Nyatana maneh mawa hirup ti kami [Alloh], anu kudu balik deui ka kami [Alloh].

13. Hirupna kami lain hirupna maneh, kade urah arek linglung pangakuan!

14. Komo eta hirup ti kami, rek wani-wani diruksak ku diri maneh, nu engke akibatna siksa hirupna, anu moal bisa ditulungan kusasamana.

15. Pek ku diri maneh geura palikiran, meungpeung kami [Alloh] mere beja ka diri maneh.

16. Di mana kami [Alloh] can nutup pikeun umatumatna anu embung ngadenge beja ti kami [Alloh]; sumun bukmun umyun pahum layar jiun.

Kun fayak kun.

Berdasar amanat ini Andreas Firman 40 menyusun sebuah protap (Copy protap AKI) mengenai implementasi ajaran yang dimulai dengan:

Kun fayak kun

Allah berfirman

Dengarkanlah olehmu! Aku sengaja

Aku obahkan

Rasa hatimu

Untuk dirimu mengerti

Siapa Aku? Siapa dirimu

Akulah yang berkuasa

Di dunia ini Lailaha Ilallahallohuakbar [dalam tulisan arab]

Akulah yang menjadikan seluruh

Alam semesta berikut isi-isinya

Dan makhluk-makhluknya. Allohuakbar [dalam tulisan arab]

Maka bersyukurlah dirimu kepada diri-Ku

Dan sampaikanlah kekuasaan-Ku

Dan nikmat-Ku yang dirimu telah

Menerimanya Allohuakbar [dalam tulisan arab] SELAMATKANLAH SESAMA UMATMU DI DUNIA 
Yang masih kegelapan hatinya, diatas

Kekuasaan-Ku Lailahailalloh Allohuakbar [dalam tulisan arab]

\section{SALAMUN QAOLAMMIRROBBI ROHIM}

Jakarta, Tgl 04 Mei 1989

Lailahailalloh Allohuakbar [dalam tulisan arab]

A.K.I

Protap ini juga merinci tahapan untuk mengikuti ajaran AKI (disalin dari protap AKI) sebagai berikut:

1. Penyampaian sinar kuasa ilahi dalam bentuk tuntun doa atau pewarisan

2. Mandi taubat dengan lafaz

3. Puasa

4. Bersyukur dengan menyembelih kambing

5. Kholwat Guha

6. Kholwat Jalan

7. Penghayatan

8. Peringatan Hari-Hari besar AKI.

Dalam kelompok ini pewarisan merupakan bagian dari ritual yang harus dilakukan bagi seseorang yang merasa terpanggil dengan panggilan tuhan sebagaimana telah dijelaskan terdahulu. Dalam pasal 14 protap AKI, disebutkan bahwa pewarisan sebagai proses upacara dalam rangka penyampaian sinar kasih kuasa Tuhan atau Nur Ilahi kepada seseorang. Selanjutnya dijelaskan bahwa seseorang yang berhak untuk menyampaikan pewarisan harus berstatus imam baik tingkat Turjaun, Nulkarim atau Firman. Imam Turjaun adalah tingkatan kedua kedudukannya dalam stratifikasi keanggotaan AKI. Selanjutnya adalah nulkarim dan paling tinggi disebut firman. Adapun yang boleh menerima pewarisan disyaratkan minimal serendah-rendahnya berusia 10 tahun (Nugraha, 2013).

Pewarisan ini dilakukan dengan memperhatikan gender, namun juga dijelaskan jika dalam darurat boleh laki-laki diwarisi oleh perempuan. Sementara dalam prosesi ini hendaknya ada saksi apalagi jika mewarisi yang bukan muhrimnya. Selain itu, dalam prosesi juga ada tatacara yang harus dilakukan serta bacaan khusus. Namun demikian, uniknya pewarisan ini dapat dilakukan oleh orang dengan beragama apa saja. Dalam protap dijelaskan empat jenis bacaan sumpah pewarisan, pertama oleh orang Islam, kedua oleh orang Kristen, Katolik dan orang yang tidak beragama formal namun meyakini adanya Tuhan.

Bacaan pewarisan cara agama Islam adalah: Takbir 3x; ta'awudz; tasmiah; syahadat; shalawat (Allohuma sholli ala sayidina muhammad wa'alla sholli alla sayidina muhammad); demi Alloh, Rosululloh, wallahi, allah hu akbar 3 x; lillahi táala. Laa hawla walaa quwwata illa billahil aliyyil aziem; ya Allohu, ya Allohu, ya Allohu (secukupnya) allah hu akbar $3 \mathrm{x}$.

Adapun bagi seseorang yang hanya mengakui adanya tuhan namun tidak beragama secara formal adalah: Ya Tuhan Yang Maha Kuasa; Ya Tuhan Yang Maha Adil; Ya Tuhan Yang Maha Pengasih; Ya Tuhan Yang Maha Penyayang; Ya Tuhan Yang Maha Pelindung; Ya Tuhan Yang Maha Penyelamat. Selanjutnya berjanji "akan setia bakti kepada-Mu Ya Tuhan; seumur hidupku. Bilamana ternyata saya mengingkari janji saya, demi Tuhan saya siap menerima hukumnya. Ya Tuhan,..." secukupnya, diakhiri dengan Tuhan Maha Besar 3x.

Dalam kumpulan amanat dari pendiri kelompok ini tidak ada yang menggambarkan bentuk ritual yang harus dilakukan anggotanya. Namun dalam protap disusun berbagai kewajiban yang harus dilakukan anggota kelompok, seperti tugas mandi ungkapan syukur, puasa dan khalwat. Mandi dalam kelompok ini menjadi kewajiban pertama setelah menerima pewarisan. Mandi ini merupakan bagian dari proses pertaubatan baik secara lahir maupun batin. Dalam prosesi mandi tersebut dilakukan oleh orang setingkat imam baik Turjaun maupun Nulkarim kepada anggotanya.

Puasa dalam kelompok AKI dibagi menjadi beberapa jenis, puasa tetapi makan nasi putih dan minum air putih yang disebut puasa mutih. Puasa dari sesuatu yang mengandung unsur garam. Puasa dengan hanya makan buah-buahan saja. Puasa dari seluruh makanan namun hanya minum saja. Puasa dari unsur makanan yang bernyawa. Puasa dengan hanya makan sayur dan buah-buahan. Puasa dengan hanya makan umbi-umbian. Puasa untuk tidak bicara. Puasa tidak bersetubuh. Puasa tidak mandi. Puasa tidak keluar rumah dan puasa dari unsur makanan pokok. Puasa tersebut ukuran lamanya mulai dari 3 hari (untuk anak-anak), 7 hari untuk kaum perempuan dewasa, 9 hari standar orang dewasa, 17, 27, 31, 45 dan 99 hari dalam tugas tertentu. 
Syukur ditetapkan dengan memotong hewa "kurban". Pemotongan hewan ini, dilakukan setiap melakukan ritual syukur seperti syukuran awal, syukuran pribadi, syukuran masalah, syukuran penyakit, syukuran besar, syukuran tutup tahun dan syukuran syukur bersyukur. Bagi kelompok AKI tidak ada pengkhususan jenis hewan bahwa harus jantan, betinapun dijadikan alat bersyukur ketika yang melakukannya adalah perempuan.

Di samping ritual-ritual tersebut, ada juga yang disebut dengan kholwat, meliputi Kholwat Guha dan Kholwat Jalan. Kholwat Guha disebutkan hakikatnya adalah sebagai balajar berpasrah diri secara total kepada Tuhan dengan meninggalkan segala urusan dan kebutuhan selama 2 hari dan 2 malam mulai dari pukul 21 sampai pukul 21 malam berikutnya. Peserta Kholwat Guha ini hanya untuk anggota berstatus imam, dan selesai kholwat ini dilakukan syukuran dengan memotong hewan. Sementara ini tempat Kholwat Guha adalah Goa Kencana di Tasikmalaya. Sementara itu kholwat jalan nampaknya merupakan upaya napak tilas atas perjalanan pendiri kelompok ini. Mulai dari Jakarta, Bandung, Leles (Garut), Banjar, Majenang, Gunung Srandil, Rajawana, Banten dan kembali ke Jakarta (srengseng). Selama di perjalanan pelaku kholwat dilarang untuk menginap di hotel tetapi dianjurkan menginap di rumah-rumah insan Nulkarim, pantai, hutan, masjid atau tempat yang dianggap keramat.

Berkenaan dengan Leles menjadi pusat kunjungan murid murid M. Syamsoe, maka AKI di Leles memiliki beberapa kegiatan rutin seperti:1) Bakti Sosial diantaranya adalah pengobatan gratis baik dilakukan secara medis maupun non medis, pengobatan bagi pencandu narkoba, penyantunan beasiswa, pemberian sembako; 2) penyembelihan hewan kurban yang jumlahnya hingga mencapai ratusan ekor Kambing dan beberapa ekor Sapi; 3) peringatan hari-hari besar kelompok AKI yaitu di antaranya peringatan petunjuk kesucian "Nur Ilahi" setiap tanggal 12 Maulud; 4) Ziarah ke Makam M. Syamsoe dan penghayatan dzikir; 4) Tempat berkhalwat di mushallah Leles (Ibu Andi, wawancara, 24/2/2016).

\section{AKI dalam Perspektif}

Bagaimana sebuah keyakinan berwujud dan berkembang merupakan kuriositas dari sekian deretanpertanyaanlainnya, termasukmaknaapayang dibangun dari sebuah ajaran. Dalam kenyataannya, agama-agama besar lahir, salah satunya, dari realitas sosial yang terhampar didepannya. Dalam konteks ini, deviasi sosial, seperti penindasan kaum lemah oleh kaum kuat, pelecehan seksual yang disertai kekerasan, penimbunan dan penguasaan distribusi kekayaan-ekonomi oleh kaum borjuis, pemerahan tenaga kerja oleh kaum berduit dan lain sebagainya yang terjadi pada waktu itu merupakan salah satu historical background kemunculan sekaligus respon agama atasnya. Agama mendobrak ketimpanganketimpangan tersebut dengan perlawanan yang luar biasa. Dalam hal ini, sejarah telah mencatat, bahwa masyarakat yang hidup sebelum agama-agama lahir mengalami persoalan yang termasuk stadium akut dalam realita kehidupannya. Kenyataan ini diperparah dengan adanya justifikasi dari para tokoh agamawan bahwa merekalah yang paling berhak untuk menentukan baik dan benar dalam persoalan agama dengan tujuan untuk melanggengkan kekuasaan serta legitimasi mereka. Akibatnya, kehidupan keagamaan pun menjadi tak menentu, dikarenakan masing-masing agamawan memiliki penafsiran masing-masing dalam persoalan agama.

Berkaca dari fenomena sosial di atas, agama lahir untuk mengembalikan posisi manusia kembali kepada ajaran sejatinya. Agama lahir untuk memberikan tuntunan dan bimbingan yang berkeadilan dan humanis dalam aplikasinya. Hal ini tentunya dibarengi dengan sejumlah aksi nyata (political will). Agama memperbaiki dan memosisikan tatanan sosial-kemasyarakatan yang telah hancur kembali kepada aspek-aspek kemanusiannya.

Ketimpangan-ketimpangan yang diakibatkan dari deviasi sosial di atas akan menyebabkan kegelisahan seorang moralis yang sebenarbenarnya. Kegelisahan dalam dirinya, lahir akibat ia melihat realitas di sekitarnya, yang tidak sesuai dengan nurani, nilai-nilai luhur dan moral, tentu, dalam pandangan seorang guru moral yang suci. Kegelisahan sang guru moral akan menghasilkan agama, mestilah untuk melakukan perubahan sosial, agar keseimbangan sistem sosial terjadi. Bahwa kemudian sang guru moral mendapatkan wahyu, atas klaim mereka sendiri yang kemudian dibenarkan oleh para pengikutnya, adalah soal lain. Yang ingin ditegaskan di sini, berkaitan dengan pelacakan asul-usul agama adalah, wahyu-wahyu itu telah menjadi justifikasi sebuah tindakan sosial bagi sang guru moral. Bahwa wahyu itu diyakini sebagai betul-betul datang dari Tuhan, lagi-lagi adalah soal lain. Sebab pada kenyataannya, sang guru moral melakukan tindakan sosial dengan mengklaim diri sebagai nabi dan rasul. Hampir 
tidak pernah ada, tradisi di mana para nabi dan rasul, tidak mendakwahkan bahwa dirinya adalah utusan Tuhan.

Dalam kasus AKI, M. Syamsoe menjadi guru moral yang memiliki justifikasi versinya atas wahyu yang diterima untuk membenahi kondisi umat manusia. Lain dari itu seperti yang dituturkan Ibu Andi (wawancara, 24/02/2016), AKI saat ini lebih merupakan jalan seseorang untuk menemukan kesejatian dirinya. Menurutnya, AKI bukanlah lembaga keagamaan yang bertujuan untuk memperdalam ilmu agama [Islam] bukan pesantren, atau lainnya, melainkan sebuah ajaran yang bersumber dari amanat $M$. Syamsoe yang bertujuan untuk memperteguh dimensi batin agar semakin tahu dan menyadari siapa dirinya (saksi diri). Ajaran ini terbuka untuk dilakukan oleh siapapun. Maka sebagai sebuah ajaran yang terbuka, AKI boleh dimasuki oleh siapapun tanpa terbatasi oleh etnis, agama maupun identitas lainnya. Seperti yang terlihat dalam perkembangan murid-murid AKI saat ini yang ada dalam tiga besaran yakni Majlis Zikir (Islam) Yaskum Bulganon (Islam) dan Andreas (Katolik) terlihat bahwa AKI tidak menjadi monopoli salahsatu pemeluk agama formal di Indonesia. Lain dari itu seperti tampak dalam pewarisan yang mengakomodir keragaman keyakinan.

Kondisi akomodatif ini bagi pihak tertentu seperti MUI dan Pakem melahirkan keputusan bahwa ada potensi kesesatan di dalamnya. Namun demikian dalam perspektif antropologi benar dan salah sebuah agama tidaklah menjadi sesuatu yang dihiraukan, seperti kesimpulan Durkheim yang dikutip Morris (2007: 138) bahwa "realitasnya tidak ada agama yang salah. Semua agama memiliki kebenaran dalam modelnya masingmasing, sekalipun dengan cara yang berbeda-beda, semuanya menjawab kondisi eksistensi manusia yang sudah ada." Konsep saksi diri yang ditawarkan AKI sebagai jalan untuk menemukan hakikat yang dimulai dari diri sendiri memenuhi pendapat Durkheim di atas. Pewarisan atau tuntun doa yang dilanjutkan dengan amalan zikir tertentuyang bagi pemeluk Islam dengan melapalkan lafaz Ya Allohu, memiliki kemiripan dengan gerakan tarekat. Meskipun seperti pernyataan Ibu Andi bahwa AKI bukanlah gerakan agama maka menepis AKI sebagai sebuah tarekat. Pewarisan atau tuntun doa lebih merupakan upaya seperti pintu pertama dalam penerimaan keanggotaan atau murid baru dalam kelompok apapun.
Sebagai ajaran yang memiliki tujuan untuk "memperbaiki" kondisi masyarakat, AKI bukanlah pihak baru. Agama atau keyakinan lain yang sudah berkembang di Indonesia pada prinsipnya dalam tataran ini memiliki tujuan serupa. Namun ketika AKI lahir dan memiliki pengikut yang tertarik dengan ajaran M. Syamsoe kembali menegaskan tesis terjadinya deviasi atau paham dan aliran sempalan merupakan bentuk protes dari status quo yang telah menjadi hegemoni elit agama atau bahkan agama itu sendiri yang mainstream. Dalam wawancara dengan Ibu Andi (wawancara, 24/2/2016) terungkap bahwa banyak di antara pengikut adalah mereka yang sebelumnya memiliki persoalan dalam kehidupan, dan mengaku memiliki kesulitan dalam penyelesaiannya. Sementara ia adalah orang yang mengaku telah beragama. Melalui AKI yang dimulai dari tuntun doa (pewarisan) dan penghayatan atas amanat, mereka yang bermasalah ini menemukan jawaban baik secara material maupun spiritual.

Secara spiritual yakni hadirnya ketenangan batin, yang dalam perspektif James (2015: 50), boleh jadi merupakan wujud pengalaman keagamaan yang sifatnya personal karena berada dalam wilayah psikologis. Sementara itu secara material, mereka yang sebelumnya memiliki masalah kehidupan baik dalam bentuk perusahaan atau pertanian yang semula diambang kebangkrutan, dengan menjadi anggota AKI dan mengamalkan ajaran AKI seolah memiliki jawaban riil atas permasalahannya tersebut (wawancara dengan Cecep 24/02/2016). Menurut tuturan Cecep, ketika isu AKI dianggap sesat mulai mengemuka, beberapa anggota kelompok bersikukuh bertahan dalam keyakinannya dengan AKI, bahkan berpendapat andai AKI adalah ajaran yang menyimpang dan sesat, maka niscaya hasil panennya akan lebih buruk dibanding tetangga sawahnya. Alih-alih bangkrut hasil pertaniannya justru jauh lebih baik daripada sawah milik non anggota AKI (wawancara 24/02/2016). Fenomena ini tentu semakin mengukuhkan keyakinan anggota AKI tentang "kebenaran" ajarannya.

Memandang agama memiliki dimensi fungsional menurut Morris (2007: 225) merupakan kerangka awal dalam beragama yang primitif dimana agama dipandang secara pragmatis. Pola hubungan yang sederhana dan tidak rumit. Kondisi wacana pragmatisme pengikut AKI yang melihat pola benar dan salah dari keberfungsian agama senada dengan temuan Bamualim yang meneliti Aliran Kebatinan Perjalanan (AKP). Salah satu poin yang terekam adalah banyak di antara 
mereka yang sebelumnya mengaku agama Islam kemudian konversi agama karena melihat adanya ketidakkonsistenan dalam pemuka agama, secara lebih jauh antara ajaran dengan penganut ajaran. Berbeda dengan yang disaksikan dalam AKP yang dipandang memiliki konsistensi yang baik dalam ajaran dengan penganutnya (Bamualim, 2015: 51).

Seperti halnya keyakinan lain, ketika ia menjadi semakin besar dan pengikutnya semakin banyak terdiri dari lintas wilayah dan etnis maka memerlukan semacam code of concuct bagi kelompok. Dalam hal ini protap AKI menjadi wujud praksis atas amanat yang disampaikan $\mathrm{M}$. Syamsoe. Protap disusun kemudian jauh setelah amanat disampaikan. Hal serupa terjadi dalam AKP. Pokok ajaran AKP baru disusun kemudian setelah ada permintaan dari Kejaksaan untuk dapat menjelaskan bagaimana sesungguhnya AKP (Rozak, 2005: 178179). Munculnya protap merupakan respon atas perubahan kondisi AKI. Protap pada ahirnya menjadi guide line bagi para anggota dan calon anggota untuk dapat memahami bagaimana AKI dijalankan. Tentu, sebagai sebuah kelompok keberadaan protap menjadi penting. Karena ia menjadi pengikat bagi anggotanya dan menunjukkan posisi masing-masing dalam AKI. Hal-hal yang dibangun dalam protap banyak yang merupakan aktifitas profan. Namun ia meningkat statusnya menjadi sakral ketika berkaitan dengan ajaran (Dhavamony, 1995: 88-89). Dalam telaahan ini, semua tahapan dalam protap AKI dapat dijelaskan. Mandi dan kholwat baik kholwat guha maupun kholwat perjalanan yang semula aktifitas biasa namun karena dihubungkan dengan dimensi ajaran maka naik statusnya menjadi ritual yang sakral.

Dalam perspektif gerakan, wahyu-wahyu yang diterima M. Syamsoe sebagai tokoh pendiri sekaligus guru moral, menjadi pendorong bagi penciptaan keseimbangan sosial dalam perspektif AKI. Beberapa orang kemudian mengikuti pikiran-pikiran dari seorang guru moral, yang telah mengklaim diri telah memperoleh wahyu tersebut. Sebagai tindakan sosial sang guru moral yang demikian, agama-agama dari asalnya muncul, kemudian mampu menyingkirkan ajaran-ajaran sebelumnya. Atau paling tidak, ajaran-ajaran itu mampu menjadi wacana tanding dalam sebuah komunitas dan menyeimbangkan hegemoni. Dengan mempertimbangkan konteks sosial sebagai salah satu unsur dalam membedah asal-usul agama, maka terlihat jelas bahwa agama-agama besar yang ada sampai hari ini juga sekte-sekte keagamaan yang lahir belakangan, muncul untuk merespon ketimpangan-ketimpangan yang terdapat sejarah pergulatan manusia sebagai pengklaim kebenaran (Ridwan, 2003: 47-49).

\section{PENUTUP}

AKI menjadi komunitas dengan sebuah ajaran yang bersumber dari "wahyu" yang diterima $M$. Syamsoe. Keanggotaan dimulai dari tradisi tuntun doa atau pewarisan yang menjadi kunci pembuka pintu kesejatian diri. Hadirnya para pengikut merupakan wujud dari keberfungsian ajaran yang dianggap mampu menjawab problematika kehidupan mereka baik bersifat spritual maupun material. Fenomena AKI mengukuhkan bahwa sejatinya manusia memang memiliki dimensi spiritual yang akan terus bergejolak untuk menemukan "kebenaran". Dalam kaitannya dengan perspektif teori fungsionalisme Durkheim, tampak bahwa komunitas AKI menjadi representasi masyaraka mekanis dimana aktifitas ritual yang dilakukan baik mulai dari pewarisan maupun ritual lainnya semakin meneguhkan komitmen anggota. Dan ini relevan dengan tesis bahwa semakin kolektif ritual dilakukan dan semakin fungsional dengan realitas maka para anggota akan semakin solid. Hal ini berarti meneguhkan eksistensi mereka dalam bentangan masyarakat beragama lainnya.

\section{UCAPAN TERIMAKASIH}

Penyusun mengucapkan banyak terimakasih kepada pihak-pihak yang telah membantu selesainya studi ini. Terutama kepada informan selaku narasumber yang berkenan untuk diwawancarai dan diobservasi untuk kelengkapan bahan analisis atas studi ini. Terimakasih juga kepada pengelola Jurnal Al-Qalam yang telah memberikan saransaran konstruktifnya serta memasilitasi penerbitan hasil studi ini.

\section{DAFTAR PUSTAKA}

Asary, M. Yusuf. 2009. 'Transformasi Aliran dan Faham Keagamaan: Kasus Amanat Keagungan Ilahi Kurnia Wahyu di Majlis Zikir dan Shalawatan" Jurnal Multikultural dan Multireligius.Vol. VIII Tahun 2009 Badan Litbang dan Diklat Kementerian Agama.

Bamualim dalam Mille, Julian dan Dede Syarif. 2015. Islam dan Regionalisme. Jakarta: Pustakajaya.

Bruinessen, Martin van. 1992. "Gerakan Sempalan di Kalangan Umat Islam Indonesia: Latar Belakang Sosial Budaya" dalam Jurnal Ulumul Quran. Vol. III No.1, 1992. 
Dhavamony, Mariasusai. 1995. Fenomenologi Agama, Terj. Kelompok Studi Agama Driyakara. Yogyakarta, Kanisius.

Dokumen Lembaran Amanat M. Syamsoe.

Durkheim, Emile. 1995. The Elementary Forms of the Religious Life. New York: The Free Press.

Gatra. AKI bukan Yaskum. Nomor 13, Kamis, 5 Februari 2009.

Hidayat, Komaruddin, Nafis, dan Muhammad Wahyuni. 1995. Agama Masa Depan Perspektif Filsafat Perenial. Jakarta: Paramadina, Cet. I.

James, E.O. 1964. History of Religion. London: English University.

James, Wiliam. 2015. The Varieties Religious Experience, Pengalaman-Pengalaman Religious. Yogyakarta: Ircisod.

Ma’mun. 2013. “Ajaran Aliran Amanat Kegungan Ilahi di Provinsi Sumatera Selatan" dalam Fenomena Aliran Keagamaan dan Perubahan Sosial. Jakarta: Balai Litbang Agama.

Morris, Brian. 2007. Antropologi Agama. Yogyakarta: AK Group.
Mulyana, Deddy. 2006. Metodologi Penelitian Kualitatif Paradigma Baru Ilmu Komunikasi dan Ilmu Sosial Lainnya. Bandung: Rosdakarya.

Nugraha, Firman. 2013. Tinjauan Islam Tentang Konsep Wahyu dan Pewarisan Amanat Keagungan Ilahi, http://www.website bdkbandung.kemenag.go.id./ journal/2013

Nurhamidah, Enda. 2010. Amanat Keagungan Ilahi di Garut. Jakarta: Badan Litbang dan Diklat Keagamaan.

Protap AKI yang disusun oleh Firman 40 (AKI Andreas) di Jakarta.

Ridwan, Nur Khalik. 2003. Detik-Detik Pembongkaran Agama: Mempopulerkan Agama Kebajikan, Menggegas Pluralisme-Pembebasan. Yogyakarta: Ar-Ruzz Book Gallery.

Rozak, Abdul. 2005. Teologi Kebatinan Sunda. Bandung: Kiblat.

Sugiyono. 2009. Metode Penelitian Kuantitatif dan RひD. Bandung: Alpabeta.

Syariati, Ali. 2000. Agama versus Agama, Terj. Afif Muhammad dan Abdul syukur. Jakarta: Pustaka Hidayah. 